\title{
Caspase inhibitor decreases apoptosis in pyrogallol-treated lung cancer Calu-6 cells via the prevention of GSH depletion
}

\author{
YONG HWAN HAN, SUHN HEE KIM, SUNG ZOO KIM and WOO HYUN PARK \\ Department of Physiology, Medical School, Institute for Medical Sciences, Centers for Healthcare \\ Technology Development, Chonbuk National University, JeonJu 561-180, Korea
}

Received July 3, 2008; Accepted August 18, 2008

DOI: 10.3892/ijo_00000099

\begin{abstract}
Pyrogallol (PG) is a polyphenol compound and is known to be an $\mathrm{O}_{2}^{-}$generator. In the present study, we evaluated the anti-apoptotic effects of caspase inhibitors in relation to changes in reactive oxygen species (ROS) and glutathione (GSH) levels in PG-treated human pulmonary adenocarcinoma Calu- 6 cells. Treatment with $50 \mu \mathrm{M}$ PG inhibited the growth of Calu- 6 cells $\sim 60 \%$ and induced apoptosis $\sim 17 \%$ at $24 \mathrm{~h}$, accompanied by mitochondrial membrane potential loss $\left(\Delta \Psi_{\mathrm{m}}\right)$. Treatment with pan-caspase inhibitor (Z-VAD-FMK), caspase-3 inhibitor (Z-DEVDFMK), caspase-8 inhibitor (Z-IETD-FMK) and caspase-9 inhibitor (Z-LEHD-FMK) significantly prevented apoptosis in PG-treated Calu-6 cells at $24 \mathrm{~h}$. PG increased the ROS and depleted GSH contents in Calu-6 cells. Treatment with each caspase inhibitor did not significantly change the ROS and GSH levels in PG-treated Calu-6 cells at 24 h. However, ZVAD significantly prevented GSH depletion in PG-treated Calu-6 cells at the late time phase of $72 \mathrm{~h}$. Conclusively, the anti-apoptotic effect of caspase inhibitor on PG-induced Calu-6 cell death was closely related to changes in GSH content rather than ROS levels.
\end{abstract}

Correspondence to: Dr Woo Hyun Park, Department of Physiology, Medical School, Institute for Medical Sciences, Centers for Healthcare Technology Development, Chonbuk National University, JeonJu 561-180, Korea

E-mail: parkwh71@chonbuk.ac.kr

Abbreviations: PG, pyrogallol; ROS, reactive oxygen species; SOD, superoxide dismutase; FBS, fetal bovine serum; MTT, 3-(4,5dimethylthiazol-2-yl)-2,5-diphenyltetrazolium bromide; PI, propidium iodide; FITC, fluorescein isothiocyanate; $\mathrm{H}_{2}$ DCFDA, 2',7'-dichlorodihydrofluorescein diacetate; DHE, dihydroethidium; GSH, glutathione; CMFDA, 5-chloromethylfluorescein diacetate; HPF, 3'-(p-hydroxyphenyl) fluorescein; MMP, mitochondrial membrane potential

Key words: pyrogallol, apoptosis, Calu-6, caspase, reactive oxygen species

\section{Introduction}

The mechanism of apoptosis mainly involves two signaling pathways, the mitochondrial and cell death receptor pathways (1-3). The key element in the mitochondrial pathway is the efflux of cytochrome $c$ from mitochondria to cytosol, where it subsequently forms a complex (apoptosome) with Apaf-1 and caspase-9, leading to the activation of caspase-3 (4). The cell death receptor pathway is characterized by the binding of cell death ligands and cell death receptors, and subsequently activates caspase- 8 and $-3(5,6)$. Caspase- 3 is an executioner caspase, whose activation can systematically dismantle cells by cleaving key proteins such as PARP.

Pyrogallol (PG) is a polyphenol compound and is known to be a superoxide anion $\left(\mathrm{O}_{2}^{-}\right)$generator $(7,8)$. This compound is often used to investigate the role of $\mathrm{O}_{2}{ }^{-}$in the biological system. The superoxide anion $\left(\mathrm{O}_{2}^{-}\right)$belongs to the reactive oxygen species (ROS) including hydrogen peroxide $\left(\mathrm{H}_{2} \mathrm{O}_{2}\right)$, hydroxyl radical $(\mathrm{OH})$ and peroxynitrite $\left(\mathrm{ONOO}^{-}\right)$. These ROS have recently been implicated in the regulation of many important cellular events, including transcription factor activation, gene expression, differentiation and cell proliferation (9-11). ROS are formed as by-products of mitochondrial respiration or certain oxidases such as nicotine adenine diphosphate (NADPH) oxidase, xanthine oxidase (XO), and a number of arachidonic acid oxygenases (12). A change in the redox state of tissue implies a change in the generation or metabolism of ROS. Principal metabolic pathways include superoxide dismutase (SOD), which is expressed as extracellular, intracellular and mitochondrial isoforms (13). These isoforms metabolize $\mathrm{O}_{2}{ }^{-}$to $\mathrm{H}_{2} \mathrm{O}_{2}$. Further metabolism by peroxidases which include catalase and glutathione (GSH) peroxidase yields $\mathrm{O}_{2}$ and $\mathrm{H}_{2} \mathrm{O}$ (14). Cells possess antioxidant systems to control the redox state, which is important for their survival. Excessive production of ROS gives rise to the activation of events that lead to death in several cell types (15-18). Also, $\mathrm{PG}$ was shown to induce $\mathrm{O}_{2}$ -mediated death of several types of cells such as mesangial (19), human lymphoma (7), human glioma (20) and As4.1 juxtaglomerular cells (21). The exact mechanisms involved in cell death induced by ROS are not fully understood.

Lung cancer is a major cause of cancer-related death in developed countries. Various novel therapeutic strategies are 
currently under consideration, as the clinical use of cytotoxic drugs is limited due to intrinsic or acquired resistance and toxicity (22). Studies of the molecular mechanisms of cytotoxic drug action have shed light on the treatment of lung cancer, and novel agents that target specific intracellular pathways related to the distinctive properties of cancer cells continue to be developed. However, little is known about the relationship between PG and lung cancer cells.

In the present study, we evaluated the anti-apoptotic effects of caspase inhibitors in PG-treated human pulmonary adenocarcinoma Calu- 6 cells in relation to changes in ROS and GSH levels.

\section{Materials and methods}

Cell culture. The human pulmonary adenocarcinoma Calu-6 cell line was obtained from the ATCC (HTB56) and was maintained in a humidified incubator containing $5 \% \mathrm{CO}_{2}$ at $37^{\circ} \mathrm{C}$. Calu- 6 cells were cultured in RPMI-1640 supplemented with $10 \%$ fetal bovine serum (FBS) and $1 \%$ penicillinstreptomycin (Gibco BRL, Grand Island, NY). Cells were routinely grown in 100-mm plastic tissue culture dishes (Nunc, Roskilde, Denmark) and harvested with a solution of trypsin-EDTA while in a logarithmic phase of growth. Cells were maintained in these culture conditions for all experiments.

Reagents. PG was purchased from Sigma-Aldrich Chemical Co. (St. Louis, MO). PG was dissolved in $\mathrm{H}_{2} \mathrm{O}$ at $1 \times 10^{-1} \mathrm{M}$ as a stock solution. Pan-caspase inhibitor (Z-VAD-FMK; benzyloxycarbonyl-Val-Ala-Asp-fluoromethylketon), caspase-3 inhibitor (Z-DEVD-FMK; benzyloxycarbonylAsp-Glu-Val-Asp-fluoromethylketon), caspase-8 inhibitor (Z-IETD-FMK; benzyloxycarbonyl-Ile-Glu-Thr-Aspfluoromethylketon) and caspase-9 inhibitor (Z-LEHD-FMK; benzyloxycarbonyl-Leu-Glu-His-Asp-fluoromethylketon) were obtained from R\&D Systems, Inc. (Minneapolis. MN) and were dissolved in dimethyl sulfoxide (DMSO) (Sigma) at $1 \times 10^{-2} \mathrm{M}$ as a stock solution, which also was used as a control vehicle. All of the stock solutions were wrapped in foil and kept at 4 or $-20^{\circ} \mathrm{C}$.

Cell growth inhibition assay. The in vitro cell growth inhibition effect of PG on Calu- 6 cells was determined by measuring 3-(4,5-dimethylthiazol-2-yl)-2,5-diphenyltetrazolium bromide (MTT) dye absorbance of living cells as described previously (23). In brief, $5 \times 10^{4}$ cells per well were seeded in 96-well microtiter plates (Nunc, Roskilde, Denmark) in the presence of $50 \mu \mathrm{M}$ PG following $1 \mathrm{~h}$ of pre-incubation with $12.5 \mu \mathrm{M}$ caspase inhibitor. After exposure to PG for $24 \mathrm{~h}$, $50 \mu 1$ of MTT (Sigma) solution ( $2 \mathrm{mg} / \mathrm{ml}$ in PBS) was added to each well, and the plates were incubated for an additional $3 \mathrm{~h}$ at $37^{\circ} \mathrm{C}$. MTT solution in medium was aspirated off. To achieve solubilization of the formazan crystals formed in viable cells, $200 \mu 1$ of DMSO was added to each well. The optical density of each well was measured at $570 \mathrm{~nm}$ using a microplate reader (Spectra Max 340, Molecular Devices Co, Sunnyvale, CA, USA). Each plate contained multiple wells at a given experimental condition and multiple control wells.
Annexin $V$ staining. Apoptosis was determined by staining cells with Annexin V-fluorescein isothiocyanate (FITC) $(\mathrm{Ex} / \mathrm{Em}=488 \mathrm{~nm} / 519 \mathrm{~nm})$, because Annexin $\mathrm{V}$ can be used to identify the externalization of phosphatidylserine during the progression of apoptosis and, therefore, can detect cells during early phases of apoptosis. In brief, $1 \times 10^{6}$ cells were incubated with $50 \mu \mathrm{M}$ PG after $1 \mathrm{~h}$ of pre-incubation with $12.5 \mu \mathrm{M}$ caspase inhibitor for 24 or $72 \mathrm{~h}$. Cells were washed twice with cold PBS and then resuspended in $500 \mu 1$ of binding buffer (10 mM HEPES/NaOH pH 7.4, $140 \mathrm{mM} \mathrm{NaCl}, 2.5 \mathrm{mM}$ $\mathrm{CaCl}_{2}$ ) at a concentration of $1 \times 10^{6}$ cells $/ \mathrm{ml}$. Annexin V-FITC (5 $\mu \mathrm{l}$; Pharmingen, San Diego, CA) was then added to these cells, which were analyzed with a FACStar flow cytometer (Becton Dickinson). For each sample, 5,000 or 10,000 events were collected.

Measurement of mitochondrial membrane potential (MMP) $\left(\Delta \Psi_{m}\right)$. The mitochondrial membrane was monitored using the Rhodamine 123 fluorescent dye $(E x / E m=485 \mathrm{~nm} / 535 \mathrm{~nm})$, a cell-permeable cationic dye, which preferentially enters mitochondria based on the highly negative MMP $\left(\Delta \Psi_{\mathrm{m}}\right)$. Depolarization of MMP $\left(\Delta \Psi_{\mathrm{m}}\right)$ results in the loss of Rhodamine 123 from the mitochondria and a decrease in intracellular fluorescence. In brief, $1 \times 10^{6}$ cells were incubated with $50 \mu \mathrm{M}$ PG after $1 \mathrm{~h}$ of pre-incubation with $12.5 \mu \mathrm{M}$ caspase inhibitor for 24 or $72 \mathrm{~h}$. Cells were washed twice with PBS and incubated with Rhodamine $123\left(0.1 \mu \mathrm{g} / \mathrm{ml}\right.$; Sigma) at $37^{\circ} \mathrm{C}$ for $30 \mathrm{~min}$. Rhodamine 123 staining intensity was determined by flow cytometry. For each sample, 5,000 or 10,000 events were collected.

Detection of intracellular general ROS and $\mathrm{O}_{2}$ - concentration. Intracellular general ROS such as $\mathrm{H}_{2} \mathrm{O}_{2}, \mathrm{OH}$ and ONOO were detected by means of an oxidation-sensitive fluorescent probe dye, 2',7'-dichlorodihydrofluorescein diacetate $\left(\mathrm{H}_{2} \mathrm{DCFDA}\right)$ or 3'-(p-hydroxyphenyl) fluorescein (HPF) (24) (Invitrogen Molecular Probes, Eugene, OR). $\mathrm{H}_{2}$ DCFDA was deacetylated intracellularly by nonspecific esterase, which was further oxidized by cellular peroxides, yielding 2,7-dichlorofluorescein $(\mathrm{DCF})$, a fluorescent compound $(\mathrm{Ex} / \mathrm{Em}=495 \mathrm{~nm} /$ $529 \mathrm{~nm}$ ). HPF specifically reacts with $\mathrm{OH}$ and ONOO and yields a bright green fluorescent product $(\mathrm{Ex} / \mathrm{Em}=490 \mathrm{~nm} /$ $515 \mathrm{~nm})$. DCF and HPF are poorly selective for the superoxide anion radical $\left(\mathrm{O}_{2}^{-}\right)$. In contrast, dihydroethidium (DHE) $(\mathrm{Ex} / \mathrm{Em}=518 \mathrm{~nm} / 605 \mathrm{~nm})$ (Invitrogen Molecular Probes) is a fluorogenic probe that is highly selective for $\mathrm{O}_{2}{ }^{-}$among ROS. DHE is cell-permeable and reacts with the superoxide anion to form ethidium, which in turn intercalates in deoxyribonucleic acid, thereby exhibiting a red fluorescence. In brief, $1 \times 10^{6}$ cells were incubated with $50 \mu \mathrm{M}$ PG after $1 \mathrm{~h}$ of pre-incubation with $12.5 \mu \mathrm{M}$ caspase inhibitor for 24 or $72 \mathrm{~h}$. Cells were then washed in PBS and incubated with $20 \mu \mathrm{M} \mathrm{H}{ }_{2} \mathrm{DCFDA}$, HPF or DHE at $37^{\circ} \mathrm{C}$ for $30 \mathrm{~min}$ according to the manufacturer's instructions. DCF, HPF and DHE fluorescences were detected using a FACStar flow cytometer. For each sample, 5,000 or 10,000 events were collected. ROS and $\mathrm{O}_{2}{ }^{-}$levels were expressed as mean fluorescence intensity (MFI), which was calculated by CellQuest software. 
A

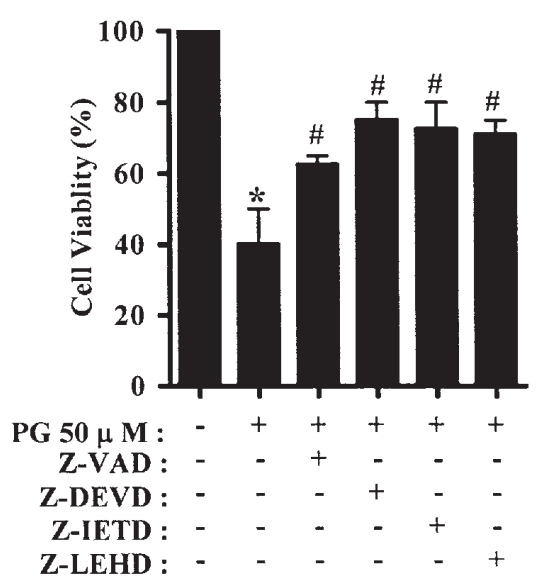

B

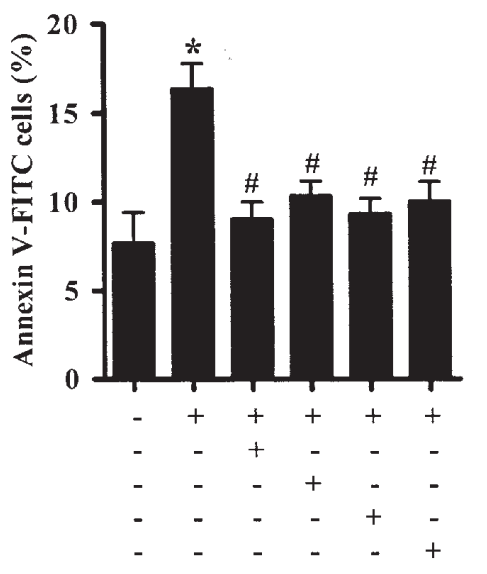

C

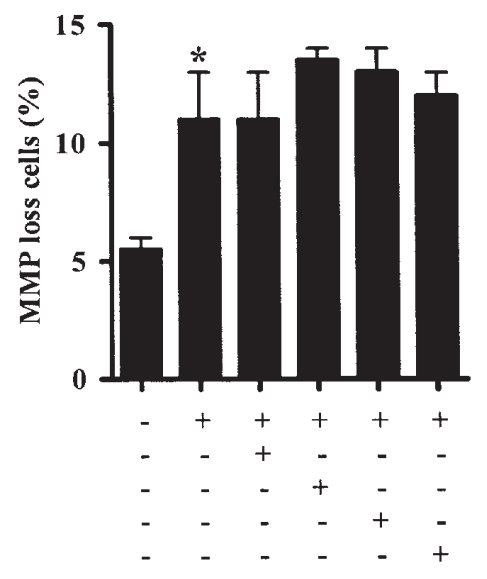

Figure 1. Effects of caspase inhibitors on cell growth, apoptosis and mitochondrial membrane potential (MMP) loss in PG-treated Calu-6 cells. Exponentially growing cells were treated with $50 \mu \mathrm{M}$ PG for $24 \mathrm{~h}$ following a 1-h pre-incubation with $12.5 \mu \mathrm{M}$ caspase inhibitor. (A) The growth of Calu-6 cells was assessed by an MTT assay. (B) Cells with Annexin V staining were counted using a FACStar flow cytometer. The graph shows the percentages of Annexin V-positive cells. (C) Cells stained with Rhodamine 123 were counted using a FACStar flow cytometer. The graph shows the percentages of Rhodamine 123negative (MMP loss) cells. ${ }^{*} \mathrm{P}<0.05$ compared with the $\mathrm{PG}$-untreated control group; ${ }^{\text {}} \mathrm{P}<0.05$ compared with cells treated with only $\mathrm{PG}$.

Detection of mitochondrial $\mathrm{O}_{2}^{-}$concentration. Mitochondrial $\mathrm{O}_{2}^{-}$- levels were detected by means of MitoSox ${ }^{\text {TM }}$ Red mitochondrial $\mathrm{O}_{2}^{-}$indicator (Invitrogen Molecular Probes), which is a fluorogenic dye for highly selective detection of $\mathrm{O}_{2}^{-}$in the mitochondria of live cells. Once in the mitochondria, MitoSox Red agent is oxidized by $\mathrm{O}_{2}{ }^{-}$and exhibits red fluorescence $(E x / E m=510 \mathrm{~nm} / 580 \mathrm{~nm})$. In brief, $1 \times 10^{6}$ cells were incubated with $50 \mu \mathrm{M}$ PG after $1 \mathrm{~h}$ of pre-incubation with $12.5 \mu \mathrm{M}$ caspase inhibitor for $24 \mathrm{~h}$. Cells were then washed in PBS and incubated with $5 \mu \mathrm{M}$ MitoSox Red agent at $37^{\circ} \mathrm{C}$ for $30 \mathrm{~min}$ according to the manufacturer's instructions. MitoSox Red fluorescence was detected using a FACStar flow cytometer. For each sample, 5,000 or 10,000 events were collected. MitoSox Red levels were expressed as mean fluorescence intensity (MFI), which was calculated by CellQuest software.

Detection of intracellular glutathione (GSH). Cellular GSH levels were analyzed using 5-chloromethylfluorescein diacetate (CMFDA, Molecular Probes) $(\mathrm{Ex} / \mathrm{Em}=522 \mathrm{~nm} /$ $595 \mathrm{~nm}$ ). CMFDA is a useful, membrane-permeable dye for determining levels of intracellular glutathione $(25,26)$. In brief, $1 \times 10^{6}$ cells were incubated with $50 \mu \mathrm{M}$ PG after $1 \mathrm{~h}$ of pre-incubation with $12.5 \mu \mathrm{M}$ caspase inhibitor for 24 or $72 \mathrm{~h}$. Cells were then washed with PBS and incubated with $5 \mu \mathrm{M}$ CMFDA at $37^{\circ} \mathrm{C}$ for $30 \mathrm{~min}$ according to the manufacturer's instructions. Cytoplasmic esterases convert nonfluorescent CMFDA to fluorescent 5-chloromethylfluorescein, which can then react with glutathione. PI $(1 \mu \mathrm{g} / \mathrm{ml})$, which is membrane impermeant and generally excluded from viable cells, was subsequently added, and CMF fluorescence and PI staining intensity were determined using a FACStar flow cytometer and calculated by CellQuest software. For each sample, 5,000 or 10,000 events were collected.

Statistical analysis. Results shown in the figures represent the mean of at least three independent experiments; bar, SD.
Microsoft Excel or Instat Software (GraphPad Prism4, San Diego, CA) was used to analyze the data. The Student's t-test or one-way analysis of variance (ANOVA) with post hoc analysis using Tukey's multiple comparison test was used for parametric data. Statistical significance was defined as $\mathrm{P}<0.05$.

\section{Results}

Effects of caspase inhibitors on cell growth, apoptosis and mitochondrial membrane potential (MMP) loss in PG-treated Calu-6 cells at $24 \mathrm{~h}$. We examined the effect of caspase inhibitors on the growth of PG-treated Calu-6 cells using an MTT assay. We screened the range concentration of PG for this experiment and chose the suitable dose of $50 \mu \mathrm{M}$ PG, which inhibited the growth of Calu-6 cells $\sim 60 \%$ at $24 \mathrm{~h}$ (Fig. 1A). We also determined $12.5 \mu \mathrm{M}$ to be the optimal dose of pan-caspase inhibitor (Z-VAD-FMK), caspase-3 inhibitor (Z-DEVD-FMK), caspase-8 inhibitor (Z-IETD-FMK) and caspase-9 inhibitor (Z-LEHD-FMK), which did not affect the growth of Calu-6 control cells (data not shown). Treatment with each caspase inhibitor significantly prevented the growth inhibition of Calu- 6 cells by PG at 24 h (Fig. 1A). Each caspase inhibitor also rescued Calu- 6 cells from PG-induced apoptosis at $24 \mathrm{~h}$ in view of Annexin V-positive staining (Fig. 1B), which indicated that the cell death of Calu- 6 cells by PG occurred via an apoptotic pathway. It is known that apoptosis is closely related to the collapse of $\operatorname{MMP}\left(\Delta \Psi_{\mathrm{m}}\right)(27)$. Therefore, we determined the loss of MMP $\left(\Delta \Psi_{\mathrm{m}}\right)$ in PGtreated Calu- 6 cells. As expected, the loss of MMP $\left(\Delta \Psi_{\mathrm{m}}\right)$ was observed in PG-treated cells at $24 \mathrm{~h}$ (Fig. 1C). However, treatment with each caspase inhibitor did not significantly change the levels of MMP loss $\left(\Delta \Psi_{\mathrm{m}}\right)$ in PG-treated cells at this time (Fig. 1C).

Effects of caspase inhibitors on ROS and GSH levels in $P G$ treated Calu-6 cells at $24 \mathrm{~h}$. To determine whether the levels 
A

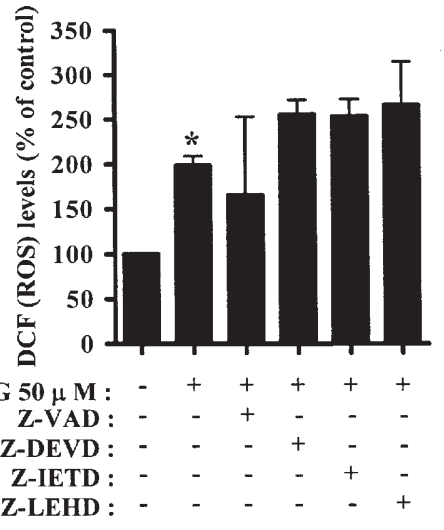

B

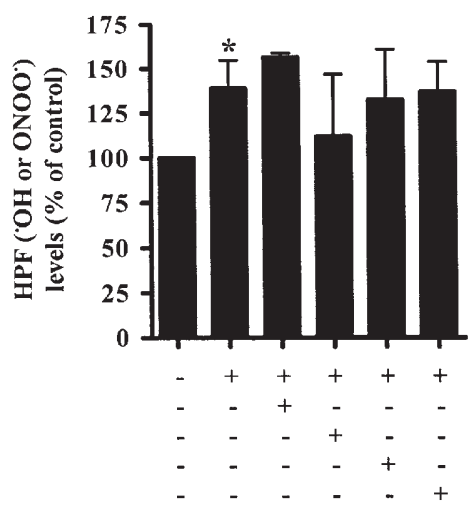

C

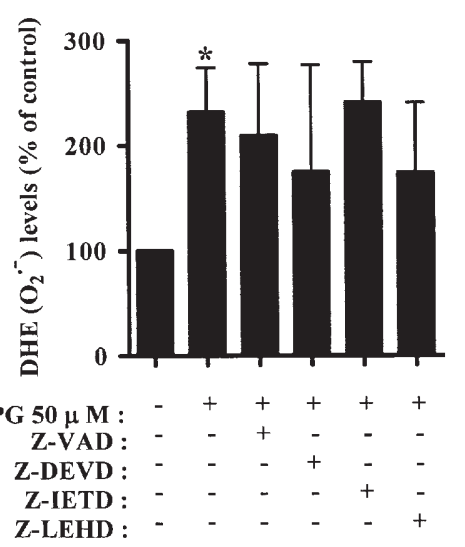

D

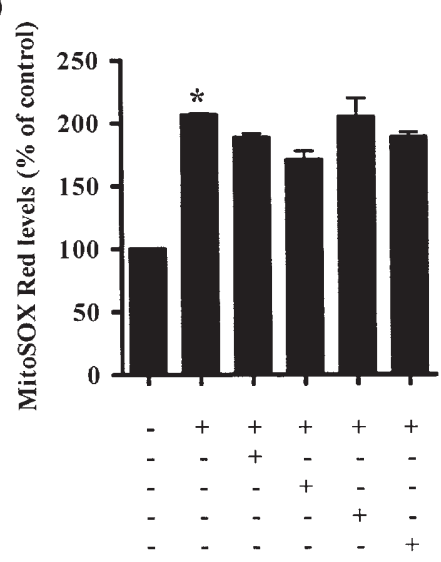

$\mathbf{E}$

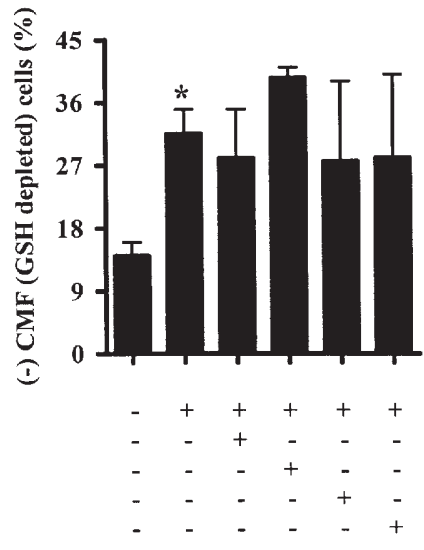

Figure 2. Effects of caspase inhibitors on ROS and GSH levels in PG-treated Calu- 6 cells. Exponentially growing cells were treated with $50 \mu \mathrm{M}$ PG for $24 \mathrm{~h}$ following 1-h pre-incubation with $12.5 \mu \mathrm{M}$ caspase inhibitor. ROS and GSH levels in Calu-6 cells were measured using a FACStar flow cytometer. (A) DCF (ROS) levels. (B) HPF ( $\mathrm{OH}$ or ONOO) levels. (C) DHE $\left(\mathrm{O}_{2}^{-}\right)$levels. (D) MitoSox (mitochondrial $\left.\mathrm{O}_{2}^{-}\right)$levels. (E) The percentage of GSH-deleted (CMFnegative) cells. ${ }^{*} \mathrm{P}<0.05$ compared with the $\mathrm{PG}$-untreated control group.

of intracellular ROS in PG-treated Calu-6 cells were altered by treatment with each inhibitor of caspase, we assessed the levels of intracellular ROS and GSH in Calu- 6 cells by using various fluorescence dyes at $24 \mathrm{~h}$. As shown in Fig. 2A and B, intracellular general ROS levels such as $\mathrm{H}_{2} \mathrm{O}_{2}, \mathrm{OH}$ and ONOO were increased in $50 \mu \mathrm{M}$ PG-treated cells. Treatment with caspase inhibitors did not significantly alter the ROS levels in PG-treated cells. When we detected the intracellular $\mathrm{O}_{2}^{-}$levels in PG-treated Calu-6 cells, red fluorescence derived from DHE reflecting intracellular $\mathrm{O}_{2}^{-}$levels and MitoSox reflecting mitochondrial $\mathrm{O}_{2}$ - levels was significantly increased in these cells at $24 \mathrm{~h}$ (Fig. 2C and D). None of the caspase inhibitors significantly altered the intracellular or mitochondrial $\mathrm{O}_{2}^{-}$levels in PG-treated Calu-6 cells (Fig. 2C and D).

Cellular GSH has been shown to be crucial for regulation of cell proliferation, cell cycle progression and apoptosis $(28,29)$. Therefore, we analyzed the changes in GSH levels in Calu-6 cells by using CMF fluorescence at $24 \mathrm{~h}$. As shown in Fig. 2E, treatment with PG depleted the intracellular GSH content in Calu- 6 cells, and none of the caspase inhibitors prevented the depletion of GSH content in PG-treated Calu-6 cells. Caspase inhibitors alone did not significantly change the levels of ROS and GSH in Calu-6 control cells at 24 h (data not shown).
Effects of caspase inhibitors on ROS and GSH levels in PGtreated Calu-6 cells at $72 \mathrm{~h}$. Since caspase inhibitors showing an anti-apoptotic effect on PG-treated Calu- 6 cells did not significantly change the ROS and GSH levels at $24 \mathrm{~h}$, we evaluated the changes in these cells at the late time of $72 \mathrm{~h}$. Treatment with pan-caspase inhibitor, Z-VAD, significantly decreased the levels of apoptosis in PG-treated cells as observed at $24 \mathrm{~h}$ (Fig. 3A). Z-VAD also decreased the MMP loss in these cells (Fig. 3B). In contrast to ROS levels in PGtreated Calu- 6 cells at $24 \mathrm{~h}, \mathrm{PG}$ did not increase but decreased the ROS levels in Calu-6 control cells at 72 h (Fig. 3C). ZVAD slightly increased the ROS levels in PG-treated cells (Fig. 3C). The intracellular $\mathrm{O}_{2}^{-}$level was increased in Calu-6 cells at $72 \mathrm{~h}$, and Z-VAD did not change the $\mathrm{O}_{2}{ }^{-}$levels in PGtreated cells (Fig. 3D).

In relation to GSH levels in PG-treated cells at $72 \mathrm{~h}$, the depletion levels of GSH in these cells were slightly higher than those at $24 \mathrm{~h}$ (Fig. 4A). Notably, treatment with Z-VAD significantly reduced the depletion of GSH content in PGtreated cells at $72 \mathrm{~h}$ (Fig. 4A). Next, to evaluate whether the M1 region cells (Fig. 4A) were dead or not, we stained cells with PI additionally to verify disruption of the plasma membrane. As shown in Fig. 4B, many negative CMF fluorescence cells by PG showed PI-positive staining, which indicated that many cells showing GSH depletion were 
A

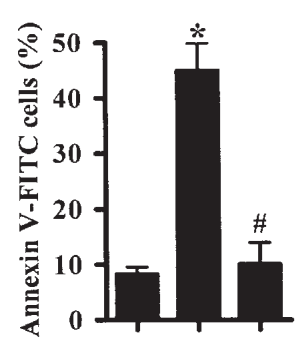

$\begin{array}{llll}\text { PG } 50 \mu \mathrm{M}: & - & + & + \\ \text { Z-VAD : } & - & - & +\end{array}$

C

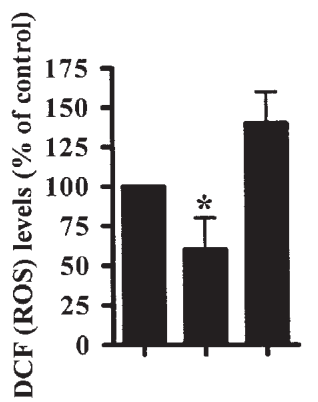

PG $50 \mu \mathrm{M}: \quad-\quad+\quad+$

Z-VAD : - -
B

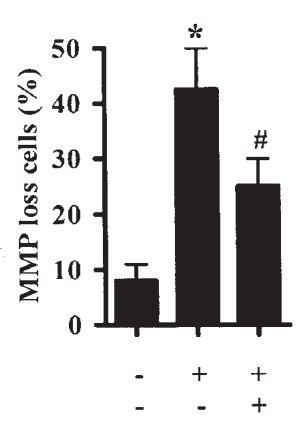

$\mathbf{D}$

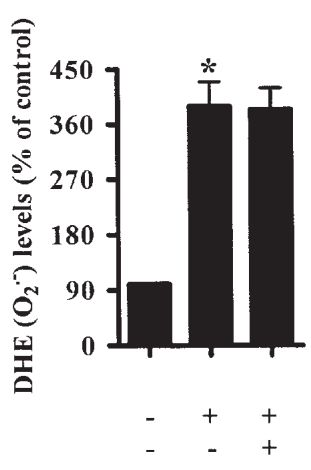

Figure 3. Effects of Z-VAD on apoptosis, MMP loss and ROS levels in PGtreated Calu- 6 cells. Exponentially growing cells were treated with $50 \mu \mathrm{M}$ PG for $72 \mathrm{~h}$ following 1 -h pre-incubation with $12.5 \mu \mathrm{M}$ Z-VAD. (A) Percentages of Annexin V-positive cells. (B) Rhodamine 123-negative (MMP loss) cells. (C) Levels of DCF (ROS). (D) Levels of DHE $\left(\mathrm{O}_{2}^{-}\right)$. ${ }^{*} \mathrm{P}<0.05$ compared with the $\mathrm{PG}$-untreated control group; ${ }^{*} \mathrm{P}<0.05$ compared with cells treated with only PG.

considered to be dead. The treatment of Z-VAD significantly reduced the number of CMF negative and PI-positive cells in PG-treated cells. The proportion of CMF and PI-doublepositive cells was small; $4 \%$ in control and PG-treated cells (Fig. 4B). Caspase inhibitors alone did not significantly change the levels of apoptosis, ROS and GSH in Calu-6 control cells at $72 \mathrm{~h}$ (data not shown).

\section{Discussion}

In the present study, we focused on evaluating the antiapoptotic effects of caspase inhibitors (pan-caspase, caspase-3, -8 or -9 ) in relation to changes in ROS and GSH levels in PG-treated human pulmonary adenocarcinoma Calu-6 cells, since we previously observed that PG inhibited the growth of Calu- 6 cells via apoptosis (unpublished data). Treatment with each tested caspase inhibitor significantly prevented apoptosis in PG-treated Calu- 6 cells at $24 \mathrm{~h}$ (Fig. 1B). The anti-apoptotic effects of caspase inhibitors (caspase-3, -8 or -9 ) on these cells were also observed at $72 \mathrm{~h}$ (data not shown). These data suggest that the activation of caspase- $3,-8$ and -9 together is necessary for full induction of apoptosis. The modes of caspase activation during apoptosis by PG may be dependent on cell type. For example, although there were differences in the incubation time and concentration of caspase inhibitors, caspase inhibitors were ineffective for rescuing cells from PG-induced apoptosis in pheochromocytoma PC12 (8), As4.1 juxtaglomerular (30) and HeLa cells (31). In particular, the inhibitor of caspase- 8 decreased the levels of apoptosis in PG-treated Calu-6 cells. The exact mechanism of PG
A
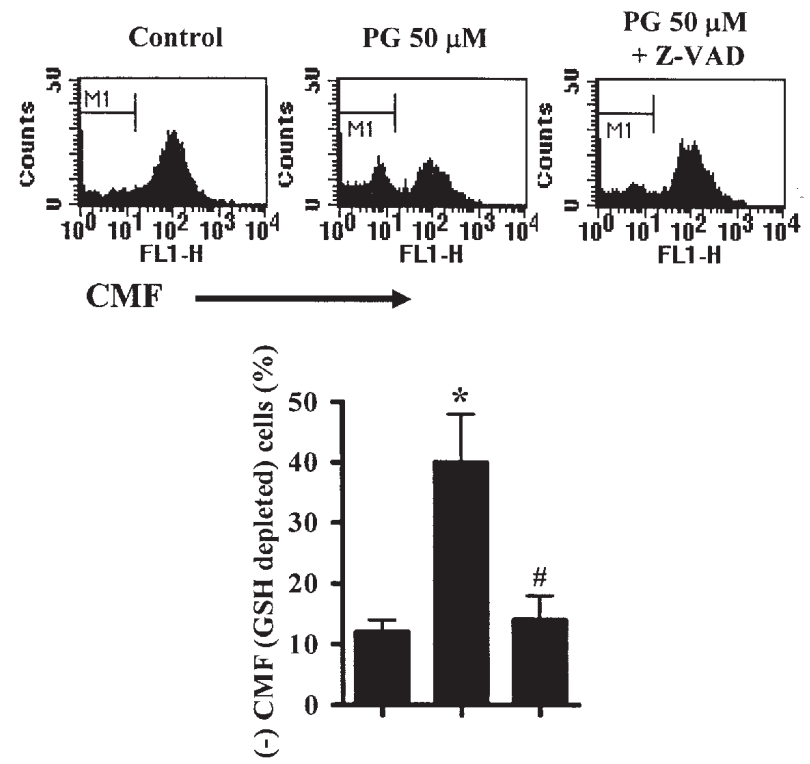

PG $50 \mu \mathrm{M}: \quad-\quad+\quad+$

Z-VAD : - - +
B
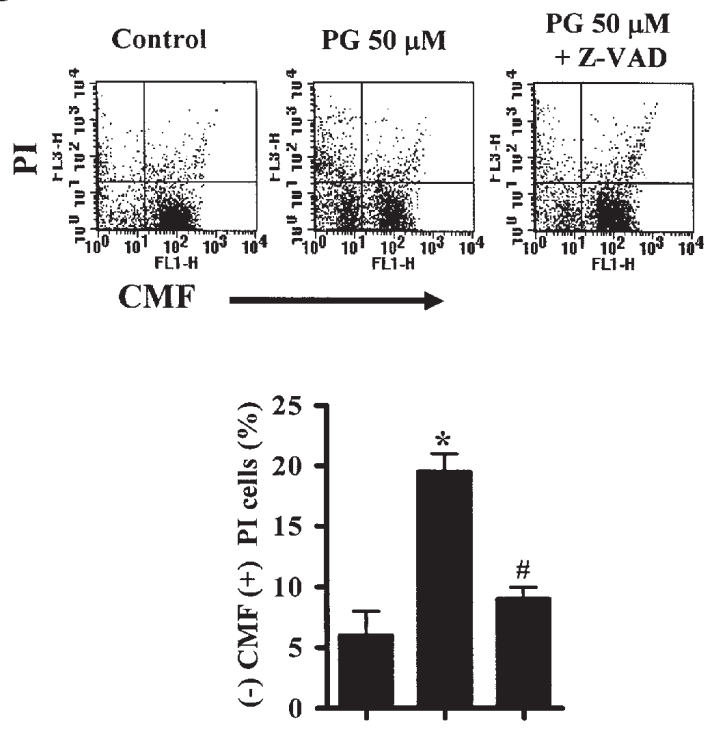

PG $50 \mu \mathrm{M}: \quad-\quad+\quad+$

Z-VAD : - $\quad-\quad+$

Figure 4. Effects of Z-VAD on GSH content and membrane integrity in PG-treated Calu- 6 cells. Exponentially growing cells were treated with $12.5 \mu \mathrm{M}$ PG for $72 \mathrm{~h}$ following 1-h pre-incubation with $12.5 \mu \mathrm{M}$ Z-VAD. (A) The intracellular GSH levels were determined by a FACStar flow cytometer. The graph shows the percent of CMF-negative fluorescent (GSH depleted; M1 region) cells from the above figures. (B) CMF fluorescent cells and PI-positive stained cells were also measured using a FACStar flow cytometer. The graph shows the percent of CMF-negative and PI-positive stained cells from the above figures. ${ }^{*} \mathrm{P}<0.05$ compared with the $\mathrm{PG}$-untreated control group; ${ }^{\#} \mathrm{P}<0.05$ compared with cells treated with only $\mathrm{PG}$. 
activation of caspase- 8 requires further study, since the activation of caspase- 8 is related to the cell death receptor pathway in apoptosis $(2,3)$. With regard to the MMP loss $\left(\Delta \Psi_{\mathrm{m}}\right)$, the loss of MMP $\left(\Delta \Psi_{\mathrm{m}}\right)$ was observed in PG-treated cells at 24 or $72 \mathrm{~h}$. Each inhibitor of caspase did not recover the loss of MMP $\left(\Delta \Psi_{\mathrm{m}}\right)$ in PG-treated cells at $24 \mathrm{~h}$, which suggests that the loss of MMP $\left(\Delta \Psi_{\mathrm{m}}\right)$ by $\mathrm{PG}$ was not enough to completely induce apoptosis in Calu- 6 cells at this time point. However, we observed that Z-VAD in part prevented the loss of MMP $\left(\Delta \Psi_{\mathrm{m}}\right)$ at $72 \mathrm{~h}$. This result also suggests that other pathways including the cell death receptor pathway, in addition to the loss of MMP $\left(\Delta \Psi_{\mathrm{m}}\right)$ by $\mathrm{PG}$, is required to entirely trigger apoptosis.

PG can disturb the natural oxidation and reduction equilibrium in cells. It has been reported that an increased pattern of $\mathrm{O}_{2}{ }^{-}$by PG is shown in pheochromocytoma PC12 (8), human neuroblastoma SH-SY5Y (32) and As4.1 juxtaglomerular cells (21). Likewise, our data showed that the intracellular ROS levels as well as $\mathrm{O}_{2}{ }^{-}$levels were increased in $50 \mu \mathrm{M}$ PG-treated Calu-6 cells at $24 \mathrm{~h}$. However, treatment with $50 \mu \mathrm{M}$ PG decreased the ROS levels such as $\mathrm{H}_{2} \mathrm{O}_{2}, \mathrm{OH}$ and ONOO for the long incubation time of $72 \mathrm{~h}$. It is possible that $\mathrm{PG}$ decreased SOD activity, resulting in slow conversion from $\mathrm{O}_{2}{ }^{-}$to $\mathrm{H}_{2} \mathrm{O}_{2}$, reduction in $\mathrm{H}_{2} \mathrm{O}_{2}$ levels, and accumulation of $\mathrm{O}_{2}$. In fact, we recently reported that $\mathrm{PG}$ decreases the activity of SOD (33). All of the tested caspase inhibitors, which significantly prevented cell death, did not significantly decrease the ROS levels increased by PG. None of the caspase inhibitors decreased the $\mathrm{O}_{2}{ }^{-}$levels in PG-treated Calu- 6 cells as well. Our results suggest that the changes in ROS by PG are not tightly related to apoptosis induction in Calu- 6 cells. The exact mechanisms of cell death due to PG and the roles of ROS in PG-treated Calu-6 cells still need to be defined further.

GSH is a main non-protein antioxidant in cells. It is able to clear away $\mathrm{O}_{2}{ }^{-}$and provide electrons for enzymes such as glutathione peroxidase, which reduce $\mathrm{H}_{2} \mathrm{O}_{2}$ to $\mathrm{H}_{2} \mathrm{O}$. It has been reported that the intracellular GSH content has a decisive effect on anticancer drug-induced apoptosis, indicating that apoptotic effects are inversely correlated to GSH content $(21,34,35)$. Likewise, our results clearly indicate that PG depleted intracellular GSH content in Calu-6 cells. In fact, ZVAD showing an anti-apoptotic effect on PG-treated Calu-6 cells reduced the depletion of GSH content by PG at $72 \mathrm{~h}$. Many CMF-negative fluorescent cells induced by PG also showed PI-positive staining, which indicated that many cells showing GSH depletion were considered to be dead. The treatment of Z-VAD significantly reduced the number of CMF-negative and PI-positive cells in PG-treated cells, indicating that Z-VAD keeps the integrity of the plasma membrane in PG-treated cells. These results suggest that intracellular GSH levels are tightly related to PG-induced cell death. However, notably, Z-VAD did not decrease the depletion of GSH content by PG at $24 \mathrm{~h}$. These data suggest that the depletion of GSH by PG at $24 \mathrm{~h}$ was not dependent on the activation of caspase but the depletion of GSH at the late time phase of $72 \mathrm{~h}$ was.

In conclusion, $\mathrm{PG}$ inhibited the growth of Calu- 6 cells throughout caspase-dependent apoptosis. The anti-apoptotic effect of caspase inhibitors on PG-induced Calu- 6 cell death was closely related to the changes in GSH content rather than ROS levels.

\section{Acknowledgements}

This research was supported by the Korean Science and Engineering Foundation (grant no. R01-2006-000-10544-0) and a Korea Research Foundation Grant funded by the Government of the Republic of Korea (MOEHRD).

\section{References}

1. Shi Y: Mechanisms of caspase activation and inhibition during apoptosis. Mol Cell 9: 459-470, 2002.

2. Ashkenazi A and Dixit VM: Death receptors: signaling and modulation. Science 281: 1305-1308, 1998.

3. Budihardjo I, Oliver H, Lutter M, Luo X and Wang X: Biochemical pathways of caspase activation during apoptosis. Annu Rev Cell Dev Biol 15: 269-290, 1999

4. Mehmet H: Caspases find a new place to hide. Nature 403: 29-30, 2000 .

5. Hengartner MO: The biochemistry of apoptosis. Nature 407: 770-776, 2000.

6. Liu X, Yue P, Zhou Z, Khuri FR and Sun SY: Death receptor regulation and celecoxib-induced apoptosis in human lung cancer cells. J Natl Cancer Inst 96: 1769-1780, 2004.

7. Saeki K, Hayakawa S, Isemura M and Miyase T: Importance of a pyrogallol-type structure in catechin compounds for apoptosisinducing activity. Phytochemistry 53: 391-394, 2000

8. Yamada J, Yoshimura S, Yamakawa $\mathrm{H}$, et al: Cell permeable ROS scavengers, Tiron and Tempol, rescue PC12 cell death caused by pyrogallol or hypoxia/reoxygenation. Neurosci Res 45: 1-8, 2003

9. Gonzalez C, Sanz-Alfayate G, Agapito MT, Gomez-Nino A, Rocher A and Obeso A: Significance of ROS in oxygen sensing in cell systems with sensitivity to physiological hypoxia. Respir Physiol Neurobiol 132: 17-41, 2002.

10. Baran CP, Zeigler MM, Tridandapani S and Marsh CB: The role of ROS and RNS in regulating life and death of blood monocytes. Curr Pharm Des 10: 855-866, 2004

11. Bubici C, Papa S, Pham CG, Zazzeroni F and Franzoso G: The NF-kappaB-mediated control of ROS and JNK signaling. Histol Histopathol 21: 69-80, 2006.

12. Zorov DB, Juhaszova M and Sollott SJ: Mitochondrial ROSinduced ROS release: An update and review. Biochim Biophys Acta 1757: 509-517, 2006.

13. Zelko IN, Mariani TJ and Folz RJ: Superoxide dismutase multigene family: a comparison of the CuZn-SOD (SOD1), MnSOD (SOD2), and EC-SOD (SOD3) gene structures, evolution, and expression. Free Radic Biol Med 33: 337-349, 2002.

14. Wilcox CS: Reactive oxygen species: roles in blood pressure and kidney function. Curr Hypertens Rep 4: 160-166, 2002.

15. Chen TJ, Jeng JY, Lin CW, Wu CY and Chen YC: Quercetin inhibition of ROS-dependent and -independent apoptosis in rat glioma C6 cells. Toxicology 223: 113-126, 2006.

16. Dasmahapatra G, Rahmani M, Dent P and Grant S: The tyrphostin adaphostin interacts synergistically with proteasome inhibitors to induce apoptosis in human leukemia cells through a reactive oxygen species (ROS)-dependent mechanism. Blood 107: 232-240, 2006

17. Wallach-Dayan SB, Izbicki G, Cohen PY, Gerstl-Golan R, Fine A and Breuer R: Bleomycin initiates apoptosis of lung epithelial cells by ROS but not by Fas/FasL pathway. Am J Physiol Lung Cell Mol Physiol 290: L790-L796, 2006.

18. Simon HU, Haj-Yehia A and Levi-Schaffer F: Role of reactive oxygen species (ROS) in apoptosis induction. Apoptosis 5: 415-418, 2000.

19. Moreno-Manzano V, Ishikawa Y, Lucio-Cazana J and Kitamura M: Selective involvement of superoxide anion, but not downstream compounds hydrogen peroxide and peroxynitrite, in tumor necrosis factor-alpha-induced apoptosis of rat mesangial cells. $\mathbf{J}$ Biol Chem 275: 12684-12691, 2000.

20. Sawada M, Nakashima S, Kiyono T, et al: p53 regulates ceramide formation by neutral sphingomyelinase through reactive oxygen species in human glioma cells. Oncogene 20: 1368-1378, 2001. 
21. Park WH, Han YW, Kim SH and Kim SZ: A superoxide anion generator, pyrogallol induces apoptosis in As4.1 cells through the depletion of intracellular GSH content. Mutat Res 619: 81-92, 2007.

22. Petty RD, Nicolson MC, Kerr KM, Collie-Duguid E and Murray GI: Gene expression profiling in non-small cell lung cancer: from molecular mechanisms to clinical application. Clin Cancer Res 10: 3237-3248, 2004.

23. Park WH, Seol JG, Kim ES, et al: Arsenic trioxide-mediated growth inhibition in MC/CAR myeloma cells via cell cycle arrest in association with induction of cyclin-dependent kinase inhibitor, p21, and apoptosis. Cancer Res 60: 3065-3071, 2000

24. Setsukinai K, Urano Y, Kakinuma K, Majima HJ and Nagano T: Development of novel fluorescence probes that can reliably detect reactive oxygen species and distinguish specific species. J Biol Chem 278: 3170-3175, 2003.

25. Macho A, Hirsch T, Marzo I, et al: Glutathione depletion is an early and calcium elevation is a late event of thymocyte apoptosis. J Immunol 158: 4612-4619, 1997.

26. Hedley DW and Chow S: Evaluation of methods for measuring cellular glutathione content using flow cytometry. Cytometry 15: 349-358, 1994.

27. Yang J, Liu X, Bhalla K, et al: Prevention of apoptosis by Bcl-2: release of cytochrome $\mathrm{c}$ from mitochondria blocked. Science 275: 1129-1132, 1997.

28. Poot M, Teubert H, Rabinovitch PS and Kavanagh TJ: De novo synthesis of glutathione is required for both entry into and progression through the cell cycle. J Cell Physiol 163: 555-560, 1995.
29. Schnelldorfer T, Gansauge S, Gansauge F, Schlosser S, Beger HG and Nussler AK: Glutathione depletion causes cell growth inhibition and enhanced apoptosis in pancreatic cancer cells. Cancer 89: 1440-1447, 2000

30. Park WH, Han YH, Kim SH and Kim SZ: Pyrogallol, ROS generator inhibits As4.1 juxtaglomerular cells via cell cycle arrest of G2 phase and apoptosis. Toxicology 235: 130-139, 2007.

31. Kim SW, Han YW, Lee ST, et al: A superoxide anion generator, pyrogallol, inhibits the growth of HeLa cells via cell cycle arrest and apoptosis. Mol Carcinog 47: 114-125, 2007.

32. Poulose SM, Harris ED and Patil BS: Citrus limonoids induce apoptosis in human neuroblastoma cells and have radical scavenging activity. J Nutr 135: 870-877, 2005.

33. Han YH, Kim SZ, Kim SH and Park WH: Apoptosis in pyrogallol-treated Calu- 6 cells is correlated with the changes of intracellular GSH levels rather than ROS levels. Lung Cancer 59: 301-314, 2008.

34. Estrela JM, Ortega A and Obrador E: Glutathione in cancer biology and therapy. Crit Rev Clin Lab Sci 43: 143-181, 2006.

35. Higuchi Y: Glutathione depletion-induced chromosomal DNA fragmentation associated with apoptosis and necrosis. J Cell Mol Med 8: 455-464, 2004. 